\title{
Defining an African Vocabulary for the Exploration of Possibilities in Higher Education
}

\section{Siseko H. Kumalo}

\section{Abstract}

In a review of Coetzee's White Writing (1988) and Gordimer's Essential Gesture (1988), Lewis Nkosi (1989) highlights fundamental deficits in South African literature. Owing to inadequate resources and statutory racial divides - instituted by apartheid - Nkosi (1989) responds to these deficits through what I interpret as a series of provocations, that posit an African Vocabulary.

Using a narrative approach I suggest a rudimentary articulation of an African Vocabulary. I explore the negotiation of power, and ethics from an African ontological framework for the purposes of reimagining an inclusive higher education system that is decolonised. This treatise facilitates my conceptualisation of an African Vocabulary in a post-apartheid, decolonial higher education landscape in South Africa through revealing colonial attempts at the decimation of African ontologies.

Through this contribution, I aim to articulate an African Vocabulary and trouble representations of African subjectivities as static and primitive. I therefore highlight and challenge sustained colonial descriptions of a gradual African epistemic framework. I frame the use of an African Vocabulary in the South African academy as an initial move towards substantive decolonisation.

Keywords: African Vocabulary, decolonisation, umDlakazi, power, identity, ethics. 


\section{Introduction}

Excavating $^{1}$ an African Vocabulary in the South African academy must be rooted in decolonising strategies to fully realise the contributions of African ontologies, in the contemporary university. Ngizobiza amagama asemandulo, I will call the names of an ancient time, I will become one with the rustling winds -ngogiya ngogubhu- and dance with the ancestors. In between the rustling winds and the resisting echoes of the trees of the veld, I will dance with my forefathers. My argument will be contentious for some, as we each lay claim to multiple identities across time and space, revealing the intersectionalities of African identities which were interrupted by the violences of colonialisms. These colonialisms plague African identities, through forced assimilation, subjugation and histories that are remembered and re-membered through tales of woe and triumph, victory and loss.

I do not maintain that my version of history is objectively correct, I merely seek to excavate the wisdom of history from my lineage through remembering the men and women who came before me. As a South African, ngizithutha ngimemeza iThongo, invoking the names of the ancient ones, I find myself KwaBulawayo, koMzilikazi, oMbulaze abamnyama, izikhali zaMantungwa. My identity constituted through this lineage is inherently linked to the dark ones, the weapons of the nation, ibutho elenqa ngokukhaliha ngaphezu'kwamanye; the Ndebele of Zimbabwe. Intrinsic to this historical project of (re)constructing identity along ancestral lines, and while I lay claim to a South African identity, my ancestry takes me to Zimbabwe illuminating the ill-conceived notion of citizenship identity imposed on an African subjectivity through western colonialisms. Evinced through these colonialisms are the continued violences which define identity(ies) from a western reading

1 The concept of excavation is used here precisely because the African Vocabulary, which is constitutive of the Black Archive, has been silenced and buried owing to colonial imposition. These impositions continue to relegate African knowledge to the periphery, devaluing the epistemic contribution of Africans. The devaluation of Africans and African modes of thought denotes an ethical harm, which has been termed an epistemic injustice in the scholarship of social epistemology. For a detailed analysis of epistemic injustice, see the work of Miranda Fricker, Epistemic Injustice: Power and the Ethics of Knowing. Oxford and New York: Oxford University Press (2007). 
of the African landscape. This misconstrual of the African landscape is what inspired Nkosi (1989) to suggest the development of an African Vocabulary. I subsequently take my que from Nkosi (1989) in this preliminary project of defining an African Vocabulary.

Through the invocation of the old names, uS'hleza, uSandile, uDzanibe kaDazakatshane, uNqolo, uMahlamb'ehlaletsheni ngenxa yokwezwela ithawula - the lives and stories of these men and women, remembered through the clan names of uScina ${ }^{2}$ inform my ontological foundations and epistemological inclinations. In their erasure, through relegating this knowledge to the realm of mythology, a relegation similar to Maitra's (2010) notion of testimonial injustice ${ }^{3}$, I am faced with the inherent ontological denial derived from colonial imposition continued by the contemporary South African university. A denial which manifests itself through a reinscribed and reaffirmed misleading logic which maintains that the western epistemic tradition is allegedly superior and the only legitimate knowledge framework within the academy.

Through privileging western epistemic traditions in an African locale - the gate-keeping of knowledge production and silencing experiential knowledge - the university produces what I have termed elsewhere the 'Native of Nowhere' (Kumalo 2018), through systematic erasures that obscure Black ontologies and their sense of belonging in the academy. The concept of a Native of Nowhere is derived from Essop Patel's, The World of Nat Nakasa: Selected Writings of Nat Nakasa (1975:75), which describes Nakasa's experience of leaving South Africa on an exit permit, only to discover that no country would give him citizenship. I understand Nakasa's experience to be a violent detachment from the land of his forebears. This visceral detachment is buttressed by the reality that his host identity denied him citizenship as he could not legitimately claim a native identity other than his own, thus he becomes the Native of Nowhere. The concept of a Native of Nowhere, when applied in the

2 The names of the Scina clan, denote and acknowledge the role of the matrilineal line ancestrally. While I am defined by a patrilineal conception of lineage, the matrilineal line defines my identity as I am formed by historic figures; omaJilajila, omaNdlangisa, oQhudeni, who constitute my ontological foundations.

${ }^{3}$ Ishani Maitra's contribution is in response to Fricker's notion of epistemic injustice as discussed above in footnote 1 . 


\section{Siseko H. Kumalo}

South African higher education landscape represents forced assimilation through epistemic impositions that demand that Black ontologies denounce their identity(ies), while never fully being embraced as Black ontology is constantly reminded of its lack of belonging in Historically White Institutions (HWIs). The act of unhoming indigeneity in the land of its forebears necessitates a reclamation of these institutions from a position which centres Blackness. The project of defining an African Vocabulary is a move in this direction.

Nat Nakasa's experience aptly describes how the contemporary university creates the Native of Nowhere, by inducing a state of oscillation through forced assimilation that rejects Blackness owing to its lack of belonging, while maintaining that its Indigenous identity is mythological and fictitious. Through this strategic act of silencing, which denies Blackness the status of a legitimate knower, the oscillation is derived from the continuous undervaluation of the knowledge held by Indigenous knowers, which is subsequently portrayed as incomprehensible ${ }^{4}$. The aims of this paper, while articulated as a coarse definition of an African Vocabulary owing to this area of scholarship being a continuation of Nkosi's (1989) project, are further to challenge the claim that would otherwise define African knowledges as incoherent and lacking intellectual rigour.

Through vexed positions of oscillation and incoherent realities, derived from incongruences in experiential knowledge pitted against institutional knowledge, I aim to continue the discussion initiated by Nkosi (1989) who proposes the development of an African Vocabulary. While I acknowledge that there might be some challenges ${ }^{5}$ with this project my aim is an attempt at a reading of ethics and ontology from an analysis of the Nguni houses, uMagubane noKumalo. The use of these two houses illustrates the

4 The concept of incomprehensible knowledge that is produced by the Indigenous knower is further evinced in the rejection of this paper without review by two South African journals prior to it being accepted by Alternation. This assertion claims that African/Black epistemologies are incoherent, underdeveloped and lack systematic rigour, a claim which this paper aims to disprove, while further highlighting the trite intellectual laziness of whiteness in the knowledge production economy of South Africa.

5 The challenges ensue from an attempt at a philosophical reading of an oral historical tradition. 
interplay of power through social realities, encapsulated in how the clan names of each responds to the other: one as innocent and the other as violent and destructive. The comparative exercise between these two houses (uMagubane noKumalo) aims to articulate an African Vocabulary. An African Vocabulary thus can be conceptualised as a lexicography which allows us to hold in tandem competing and contradictory perspectives which coincide in the manifest reality of negotiated identities. This lexicography further suggests a humble proposition of what might constitute the core of an African university. Provocatively framing an African university as premised on an African Vocabulary should not be mistaken as an elision of the institutional duties of teaching, learning and research, but rather denotes that these basic functions be undertaken in line with the intention of advancing intellectual articulations of African epistemologies in the South African context. These intellectual articulations serve the purposes of strengthening the fourth tenet, which now governs higher education in South Africa; community engagement.

\section{Articulating an African Vocabulary}

With the objective of showcasing the epistemic value and contribution of African epistemic positions through an exploratory articulation of an African Vocabulary, I begin with a dialogical recitation of the clan names of uMagubane noKumalo:

Ngibingelela koNkomose, koJiyane, koNdlandla, wena wakwaMpahle'mhlophe, ingabamnyama yeza nomdlakazi. Ngibingelela oMagubane, oNkomose, oJiyane izithuthwa ezidala, ezahamba lomhlaba, zithungatha zakh'isizwe. Isizwe esakhuluma nezizwe, kaze izikhali babezithathephi? KungezaMantungwa, oMbulaze abamnyama, abaletha ubumnyama beza nomdlakazi. OMabaso, ababas'entabeni ilanga lishona, bebikezela ukuza komDlakazi ngokukhothamisa izizwe zabangesheya koThukela! Isandla sikaMzilikazi esakha isizwe, omuzi wakhe wagcotshwa ngegazi lesitha sikaNdaba. Sikhulekile!

When calling these names, I am constituting my being, in an historical lineage of the men and women who came before me. Through this recitation which resembles a form of libation I am forced to acknowledge that my being, 
is linked to the ancestral realm of the spirits of the men and women whom I invoke when reciting the names of oMbulaze abamnyama, izikhali zaMantungwa ezawela iZambezi 'gcwele. This invocation is indicative of the interplay of power and ethics captured by a linguistic dialogical relation between imizi kaMagubane noKumalo, while revealing the dynamics of social relations in Nguni ontologies, preserved in history through clan names. Resultantly, my aim here is to discern what philosophical insights might be gleaned from historical recollections about ethics and power using a semantic analysis of the names of uMagubane noKumalo.

\section{Ngibingelela}

The concept of ukubingelela seeks to remember and re-member the ancestors as they are recalled owing to their role in history, which tells stories of how a house $^{6}$ came to be, how it conquered ngezikhali zaMantungwa. The abovementioned libation which can also be understood as a greeting which invokes the names of the ancestors and allows the living, liminality between two worlds, the worlds of the living and the living-dead. Grappling with the interplay between modernity and tradition Zakes Mda's tale, The Heart of Redness (2000), reveals this liminality through the dance of abaThwa. Mda's tale is indicative of a reading of the African landscape through an African Vocabulary making it central to my analysis. The songs of ubungoma, the act of going in and out of trance, which allows one to dance in the winds with the spirits of the ancestors, is a conceivable reality from a Nguni subjectivity, while further expressing the epistemic and ontic-ontological foundations that constitute Nguni cosmology.

A discourse of denial, which defines my cosmology as mythology, lacking any epistemological value, because these modes of knowing do not meet the standards of western knowledge structures, constitutes colonial

${ }^{6}$ House as I use it in this context denotes the lineages that constitutes a people. ${ }^{7}$ The dance of the abaThwa allowed the Believes to remain in contact with the world of the living-dead through entering into trance. This dance expresses the interplay between the living and the living-dead who play a key role in influencing the moral and ethical behaviour among the living. Once offended the living-dead/idlozi have the capacity to bring misfortune and great harm upon those who have offended them as detailed in Mda's tale. 
discourse which maintains and perpetuates violences on my subjectivity. While colonial discourse is constituted through a fetishizing of the Blackbody which Bhabha (1983: 34) captures aptly when he writes, 'the black is both savage (cannibal) and yet the most obedient and dignified servant (the bearer of food)', highlights the position to which Blackness has been consigned. This constriction connotes how Blackness has been conceptualised as a perpetual contradiction in the eyes of the western coloniser and serves the purpose of legitimating the actions of whiteness, which relegate Nguni epistemic frameworks to the periphery. This denial is elucidated by Minh-ha (1989: 15), who navigates the stories of women who are continually 'asked to substantiate their positions through performing their pain', and a further issue concerning coloniality is addressed by Almeida (2015) who argues that the subaltern has always existed as a substantiation of western civilization. Through the imposition of western forms of knowing, the Nguni body lives merely to substantiate western epistemology in the academy.

The argument that proclaims the contradiction, which is the Blackbody, reveals the tension between tradition and modernity. Tradition, which has been misconstrued and reconfigured through colonialisms which are synonymous with contemporary western modernity, defines my Blackness as savage, untamed and dangerous. In contrast, modernity continues the colonial narrative through defining my Blackness as the obedient subject, who has embraced the civility which came with the colonial mission. In the wake of this banal binarism, Lewis Gordon (2014) sketches out the decision which the colonised subject must make; assimilation or death. The option between assimilation and death, foregrounds the denial of Nguni ontology and subjectivity in the academy and further alludes to the violences which I explore in this argument through a systematic analysis of the names of uKumalo. Extensive literature explores the relationship between Blackness and colonialism see (Abarahams 2003; Lebakeng, Phalane \& Dalindjebo 2006; Gqola 2001; Gqola 2012; Mamdani 2013; Das 2007; and hooks 1992), however the project of this paper is to begin defining an African Vocabulary through the exploration of oral history. Therefore, a return to Mda's (2000) text is necessary.

In The Heart of Redness Mda (2000) hints at the devastations (Nguni) African peoples caused one another, while revealing social organisation in traditional Nguni custom, to which I will return momentarily. In acknowledging Mamdani's (2005) caution that traditional and customary 


\section{Siseko H. Kumalo}

identities are inherently descendants of colonial state legacy, I propose to tease out the ethics which governed Southern African societies expressed through the lens of pre-European-colonial imposition. In so doing, I am not proposing to define political identity through a precolonial prescriptive interpretation. Rather my aim is to work through the meeting point, the moment of contact, the decolonial moment ${ }^{8}$. Mda (2000: 141) nuances the decolonial moment through the contemporary squabbles between the Believers and Unbelievers, with the Believers maintaining that 'giving up land is a small price to pay in return for civilisation'. Mda's (2000) tale is instructive for two reasons. First, in the forfeiture of land in order to attain civilisation the Nguni body sold itself into the capitalist market conceptualised here as coloniality. Secondly, through land dispossession, which led to Nguni peoples being forced into the colonial market, Grosfoguel's assertions become clear, in the claim that modernity is synonymous with coloniality (2007: 218). Mda (2000) further illustrates how, at the moment of contact between Blackness and whiteness in South Africa, there was the creation of division within Nguni society, those who were working with the colonial administrators i.e. Twin-Twin and the alternative position, his twin brother Twin. In revealing the collaborations between Blackness and colonial power, Mda (2000) concurs with Mamdani's (2005) caution that cultural identity, premised on a precolonial conception fails to recognise the dialogical interchange between Blackness and whiteness. This dialogical interchange will form the premise for my claim of a pedagogy of obligation.

Falola (2008) laments precisely what Mamdani (2005) maintains happened when colonisation met resistance. Through the 'brutal subjugation' of monarchs who questioned British legitimacy in Nigeria and the 'installation of chiefs' who advanced the colonial agenda, Falola (2008: 95) illustrates how an identity formation project, located in a precolonial conception of society can be misleading as contemporary identities are influenced by colonial encounter.

${ }^{8}$ The decolonial moment as explained by Grosfoguel denotes the moment of contact between the colonial settler and the native subject. Historically this moment has been defined by violence and conquest, necessitating that the native engage in liberation struggles to attain their freedom, using violence izinyane lemvubu kalidliwanag ingwenya kwacweba iziziba (Nxumalo \& Nyembezi 1966: 158). An action of violence that is dehumanising, necessitates that the oppressor be reminded of the personhood of the oppressed. 
I reiterate my aim is not to define an African identity out of an analysis of precolonial Africa. Rather, the aim is to tease out the philosophical questions which arise out of the decolonial moment and proffer preliminary definitions of an African Vocabulary which aids the articulation of a post-conflictual pedagogy ${ }^{9}$.

In the term Ngibingela therefore, we begin to see the inherent complexities which are navigated by the Nguni/Black scholar, who is pressed through the act of ukubingelela, to remember and re-member untold histories. When invoking the names of the old ones we are confronted with a history of shifting identities, where at once, my Blackness can signify the oppressed while also being the signifier of oppression denoting the deposed monarchs and the installation of chiefs who brought about the European-colonial order. This dualistic reality of subjective history foregrounds the need for a pedagogy of obligation in our context, for the purposes of reimagining higher education. Through the systematic exclusion of this complex and intertwined experiential knowledge in the university, it is no wonder, the academy is creating Natives of Nowhere. Through an academic project which denies African subjectivity the tools with which to understand and interpret these historical realities, the university creates an oscillating Native of Nowhere.

\section{Wena wakwaMpahl'emhlophe}

Purity and innocence are heralded by this commendation afforded uMagubane. Wena wakwaMpahle'mhlophe, the one who comes from the house of purity. There are two understandings of purity which I wish to address in line with the reality of European colonialisms. The first being whiteness' move to spaces of innocence which absolve any guilt ensuing from the project of colonialism/coloniality. DiAngelo (2011) terms this retreat, White Fragility ${ }^{10}$,

9 The term post-conflictual pedagogy is taken from the work of Jonathan Jansen (2009) who writes about the challenges which continue to plague the South African pedagogical project. These challenges emanate from the historical legacy of apartheid in our context.

10 'White Fragility is a state in which even a minimum amount of racial stress becomes intolerable, triggering a range of defensive moves. These moves include the outward display of emotions such as anger, fear, and guilt, and 
while Tuck and Yang (2012) showcase the problematics of this retreat, by revealing how it secures white settler colonial descendent futures.

Spaces of white fragility are created when 'colonial resistance erupts' (DiAngelo 2011: 54), signalling decoloniality in praxis; a shift away from decolonisation as 'metaphor' (Tuck \& Yang 2012). This shift redefines decoloniality and gives it both agency and urgency while giving legitimacy to the Nguni/Black subject, within the academy. Tuck and Yang (2012) direct me to the nature of settler colonial education, which has become the pervasive dominant epistemological position in the world and expects to be regarded as universal. In making claims for universality through what Grosfoguel (2007: 214) calls the 'sub-zero, God-eye knowing position'; western knowledge appropriates other epistemologies while erasing the progenitors of those knowledge frameworks. This erasure represents the situation in the contemporary South African academy, through the privileging of voices of whiteness and its epistemic frameworks. This situation is what ultimately led to the violent eruptions we witnessed in the academy in 2015-2016. However, I wish to turn to the second meaning of purity, the innocence of the untainted one; an analysis that precludes whiteness. As the clan-name denotes wena wakwaMpahl'emhlophe - wendlu kaMagubane - and not whiteness. Though acknowledging the dialectical relationship between Nguni identities i.e. Blackness and whiteness is imperative as it informs how we come to understand the decolonial moment, I need not exhaust this debate here as it has been dealt with in various works, of which Bhabha's (1983) work has been of immense import (see Rutherford 1990).

How then was uMagubane perceived, if he was praised for his childlike innocence and purity? Ingabamnyama, yeza nomdlakazi! Dare taint the innocence, the purity, the childlike nature of his spirit, surely that will be a force which will come with destruction. In the process of nation building, uMagubane - I suspect, along with his successors and those loyal to his nation building project - suppressed voices of dissent, ngabe izikhali babezithathephi? Through framing uMagubane with childlike purity and innocence, it becomes the objective of Inyosi, to silence those uMagubane has subjugated. In the complexity of the power relations which are envisaged in this process of framing and reframing history, we are presented with ethical

behaviours such as argumentation, silence, and leaving the stress-inducing situation'. 
questions. Is Inyosi to reveal the true nature of uMagubane, or is he to conceal the workings of power to ensure stability and longevity to the house of uMagubane? To assume that the history of uMagubane conceals certain realities reveals how Nguni epistemology is re-membered, owing to the numerous disjunctures of colonialism and coloniality. Ensuing from the tension between the colonial settler and the native/indigenous subject, at the decolonial moment; which histories are told, what modes of reframing take place within the academy and subsequently which voices are privileged? Miriam Makeba, one of South Africa's leading anti-apartheid artists proffers a suggestion to this question,

the conqueror writes history, they came, they conquered, and they wrote. Now you don't expect people who came to invade us to write the truth about us, they will always write negative things about us, and they have to do that because they have to justify their invasion.

The epistemic injustices through reconfigurations which manifest through the erasure of Nguni epistemologies, either through 'brute force' as detailed by Falola (2008: 89) or colonial constructions as argued by Mamdani (2005) and Mda (2000), clearly indicate the ontological negation which creates the Native of Nowhere. The academy continues to perpetuate the creation of the Native of Nowhere, through the curriculum taught and the mimetic pedagogical praxes replete within the South African university. The conqueror wrote history, and it is that history that continues to be substantiated through the relegation of African epistemic positions to the periphery.

It is from the perspectives that portray uMagubane with innocence, purity, and the untainted spaces, Wena wakwaMpahle'mhlophe, Ingabamnyama, yeza nomdlakazi!, that I maintain the need for the project of re-framing and re-membering history so as to inform new imaginative possibilities for the future of higher education in our context. In the moment at which this innocence and purity are tainted, it will come with destruction, violence and elaborate displays of power. The violence and destruction that I allude to here is envisaged in the raiding of the resources of the Unbelievers by their own families in Mda's (2000) The Heart of Redness. As the colonial project is advancing aided by the imposition of English law among the Xhosa people, there is the annihilation of social organisation expressed through preEuropean-colonial Xhosa custom (Mda 2000). This systematic erasure, 
narrated through the cautionary words of Twin-Twin (Mda 2000: 154), vividly invokes the idiomatic phrase - impi isesendeni - war erupts amongst the fathers' progeny. Disjunctures of colonialism are envisaged in brothers turning against each other, wives leaving their husbands and children disserting their father's houses, a sure sign that impi isesendeni. In the wake of these disjunctures and dysfunctions which come with colonialism and coloniality, the prophecies of Nongqawuse are nuanced by the lament of pure desperation uttered in anguish owing to the desolation of social structures and the reality of being in a foreign land, 'Baba noMama nje ng'selo'khalweni, uBaba uday'se ngam' kubafokazane - ngahlupheka. Izizwe zonke zimbonile uBaba, uBaba uday'se ngam 'kubafokazane' (Buselaphi 2012).

The above lyrical composition responds to the suggestions in The Heart of Redness, that land would be a small price to pay for modernity (Mda 2000). I maintain that the forfeiture and dispossession of land creates of Nguni subjectivities Natives of Nowhere in constant oscillation as these subjectivities neither belong to their host identity, manifesting as the coloniser nor to their native identity which has otherwise been viscerally erased. This lament gives voice to the subjugated and voiceless ${ }^{11}$ in the nation building projects of these two houses, uMagubane noKumalo.

\section{KungezaMantungwa, oMbulaze abamnyama}

I now turn to interrogate the clan names of uKumalo with the intention of revealing colonial imposition, perpetrated by Nguni against Nguni. The arsenal represented through izikhali zaMantungwa, oMbulaze abamnyama, abaletha ubumnyama beza nom 'Dlakazi! sums up the colonial project of uMzilikazi.

UmDlakazi denotes destruction, war, conquest and ultimately subjugation. Ingabamnyama, yeza nomdlakazi. In tainting the purity and the innocence of the image of the house of uMagubane, weza nomDlakazi. Claiming the innocence that is created by Inyosi as he reframes, remembers and re-members history, uMagubane is created as an innocent actor in his

\footnotetext{
${ }^{11}$ The concept of voicelessness is used to detail the nature in which the colonial project, whether spearheaded by Magubane, or Kumalo, coloniality functions to silence certain voices. The nation building project of both Magubane and Kumalo comes with great sacrifice through presenting two alternatives to conquered bodies: assimilate or die.
} 
nation building project. Through the skilful prose of Inyosi, uMagubane is framed as innocent in the subjugation of those who became associated with his name. Mohanty (1993: 42) substantiates this point through the argument that distinguishes between the essentialist perspective and the post-modern conception of identity ${ }^{12}$.

The concept of umDlakazi ascribes purity to uMagubane through contradistinction, wena wakwaMpahle'mhlophe, Ingabamnyama, yeza nomDlakazi. For darkness came with the dark ones, oMbulaze abamnyama, izikhali zamaNtungwa. This is the claim made by Inyosi, implicitly, in the construction of uMagubane's identity through childlike innocence. The identity performance, through the prose of Inyosi, leads to the pacification of those who may seek to reveal the truth about their reality, which is now subsequently reframed by Inyosi. The reality relayed through the words of Inyosi introduce the concept of umDlakazi bringing about the semantic dialogue rather between the house of uMagubane noKumalo ${ }^{13}$. UKumalo through the actions of uMzilikazi, becomes associated with violence, destruction and the forced assimilation of those who would reject the legitimate rule of uMzilikazi. Inherent to the concept of $u m D a l a k z i^{14}$ is the political action of destroying those who would challenge uNdaba - Ngoba aba ludaba ezitheni zakhe.

The demand that African ontologies be seen as legitimate through the African Vocabulary is signalled by the contestations which rocked higher education between the 2015-2016 academic years. Understanding the violence

${ }^{12}$ Mohanty maintains that ' $[\mathrm{t}]$ he most basic questions about identity call for a more general re-examination of the relationship between personal experience and public meanings' (1993: 42). Mohanty is further useful for the argument being advanced here as she writes, 'the relationship between experience and identity is a genuine and philosophical theoretical issue' (1993: 42).

${ }^{13}$ Understanding the role of uKumalo as umDlakazi denotes the destruction and turmoil that was associated with uMzilikazi's nation building project in Kwabulawayo.

${ }^{14}$ umDlakazi as I use it in this context should not be compared to the colonialism of white settlers, as this would be a dangerous conflation of histories tantamount to eliding the historical realities of the impacts of white colonial settlers. I will discuss this distinction in the section that follows, distinguishing between the colonialism of Indigeneity and that of white colonial settlers. 
which engulfed the university sector recently through the language of umDlakazi, suggests that the failure to acknowledge the African Vocabulary ${ }^{15}$ creates an imminent danger which and intimates to a possibility that this failure may herald the academy being razed to the ground. This suggestion comes as the contemporary university has continuously failed to recognise the humanity of those who have existed as Indigenous beings, well before the arrival of settler colonialism. UmDlakazi, as such, becomes the capacity through which Indigenous subjectivity can lay claim to a legitimate existence within the academy, owing to how it has been denied, erased and marginalised. While Nguni epistemic positions have existed, at times in fear of whiteness, this fear has continually dissipated and threatens the academy if Indigenous epistemic positions are continuously relegated to the periphery.

Mda's text reveals something of this nature. In The Heart of Redness, Mda makes the argument of how civilization was seen as the erasure of culture, custom and the traditions of the Xhosa people, in the 'imposition of English custom presented as Christian civilisation' (2000: 237). Christian civilisation had devastating effects in the ways in which it created impi yesende as argued above. The entire fabric of society became undone, as brothers of the same womb wished each other ill-will with roaring indignation. This is envisaged in how Twin and Twin-Twin come to relate to one other at the setting of the sun, with vile hate and a deep sense of loathing. Mda's (2000) text reveals these filial antagonisms and gives an intimation towards an understanding of social organisation in both the time of colonial settlement and contemporary society. UmDlakazi as a decolonial emancipatory tool becomes a means through which the disjunctures and dysfunctions of colonialism become comprehensible through epistemic frameworks which are neither imposed nor mimetic.

Izikhali zaMantungwa, oMbulaze abamnyama, this was the war regiment of uMzilikazi, uMzilikazi kaNdebele, owakha isizwe kwaBulawayo (the place of death), omuzi wakhe wagcotshwa ngegazi lesitha sakhe. When tracing my lineage - as a South African citizen, I find myself kwaBulawayo in Zimbabwe. Yet in tracing my history I cannot claim kinship to this identity

15 The acknowledgment of an African Vocabulary should not be misconstrued as an act of merely privileging African languages in the South African university. Acknowledging the African Vocabulary suggests the creation of a lexicography which holds in tandem competing and even contradictory identities and subjectivities, with the aim of positing alternative futures. 
based on the impositions of Christian civilisation ${ }^{16}$. As a South African citizen, living in a post-apartheid state, the arbitrary boarders imposed on our countries leave me wanting for this identity, based on the ways in which colonial segregation defined ethnicity and the native, as argued by Mamdani (2005). Mamdani's (2005) thoughts on political identity in post-colonial Africa, suggests that the meeting of black and white defines today's reality; our continued struggle with European colonialism. In the instance of an identity obfuscated by the disruptions of white settler colonialism, how do we understand identity, with all its variables in the midst of trying to excavate histories which inform contemporary identity(ies)?

Colonial settlement on the African continent which came through Christian civilisation brought with it another form of umDlakazi, oweza nobumnyana - the destroyer, who came with the aim of annihilating African ontologies and modes of being. Grosfoguel (2013) in writing about the structure of knowledge in westernised universities reveals epistemic racism and sexism on the premise of hierarchies. Through privileging western knowledge while silencing local knowledges in the university, there is a clear case of ontological negation ${ }^{17}$ (see Kumalo 2018) arising from the epistemic injustices committed and sustained through the practices of the academy. In the use of the knowledges of Indigenous peoples without the recognition of where that knowledge originates, there is the erasure of a people, a silencing of voices and a continued privileging of western epistemological frameworks. Through continued silences, imposed by the relegation of experiential knowledge to the realm of mythology, the university continues to create the Native of Nowhere.

Agreeing with Mamdani (2005), when he makes the argument that the African post-colonial state remains in the clutches of collapsed coloniality, I

${ }^{16}$ I use Christian civilisation on two counts here; the first denoting how indigenous subjectivities such as uMzilikazi's nation building project was seen as barbaric, heathen and the celebration of his historical achievements is otherwise viewed as a form of nostalgia for this heathen way of life. The second connotation to Christian civilisation connotes the barbarism of the European colonial incursion which, through the Berlin conference of 1884, pierced apart families, peoples, and ways of being.

${ }^{17}$ In another argument, I have extensively detailed the negation and abjection of Blackness/ Indigeneity in Historically White Universities in South Africa. 
seek to articulate the South African moment as a mutable decolonial moment through the use of an African Vocabulary. Decoloniality is intrinsically marked by the colonial moment and assumes the modality of resisting subjugation and the annihilation of the ways of life of the Indigenous being. UmDlakazi epitomised through the actions of $u M z i l i k a z i$, represents both resistance against annihilation and the violence which ensues from white colonialisms resulting in the rupturing of the academy through subsequent resistance(s) to immanent colonialisms. UmDlakazi, the violence which Ramose (2016) calls democratic violence, can bring with it the rebirthing of the academy, for it is only in the destruction of what once existed, that there can be liberation from a system of oppression/coloniality and subjugation. Can we then make the argument for total annihilation as the only way of rebirthing the academy? In light of the chaos wrought by umDlakazi, Inyosi pacifies those subjugated by uMagubane through ascribing to his name purity, innocence and a childlike manner. The reframing of uMagubane aims to address the retelling of history in a palatable way. UMagubane is created as innocent, while the violence exhorted by uMzilikazi is exalted. Historical narratives constructed by the telling of history through the names of those who came before us, illuminates how the African Vocabulary allows us a moment's gaze into the possibilities of creating anew, the academy.

\section{Sikhulekile}

An analysis of greeting, which demonstrates customary actions involved in the process, reveals numerous epistemological positions in Zulu cosmology. At the gates, diplomatic envoys and guests - oMagubane would declare themselves before entering, Sikhulekile! Siyakhuleka koNdaba, koMbulaze, koMashobane, nina enadla umuntu nimyenga ngeNdaba... thina bakoMagubane, bakoNdlandla, bakoJiyane, bakoNkomose, thina bakwampahl'emhlophe ingabamnyama yezanomDlakazi... we have arrived, we are greeting and come in peace. It is only after this moment that those who are guests can be granted access; through declaring their arrival, stating their names and invoking the names and history of their hosts, demonstrating that they acknowledge the humanity of their hosts. This was the custom, and those who did not declare themselves, beza nomDlakazi.

The act of entering the house of another without invitation, signals the crudest disrespect, and denial of the personhood of those whose house one 
enters. The custom of greeting reveals yet another mode of complexity, as uMzilikazi did not subscribe to this custom in his nation building project. UMzilikazi's actions reveal the stark fact that in remembering and remembering history, there is seldom room for absolute innocence, either on the part of Indigeneity or white settler-colonialists. However, a qualification needs to be made, while the charge of no room for innocence might be levelled against both Indigeneity and white colonialism, it becomes imperative to acknowledge the distinctions of destruction and discontinuities caused by each; Indigeneity and whiteness. In the academy, the traditions, mores and values which govern colonial institutions, signify the latter - an entry into the land and territories of ones' hosts - without recognition of the history and humanity of the host and without invitation from the host.

Ngibingelela. Ngithokozisa iThongo - giving thanks to the ancestors for your existence. Isibingelelo here is an ontological declaration, which necessitates a rethinking of assessment and learning in higher education (Boud \& Falchikov 2007), which creates inclusive knowledge frameworks. Reconceptualising learning as inclusive of knowledges which emanate from Indigenous epistemes, allows the university to subvert its continued role of creating the Native of Nowhere. This subversion gives rise to the imagination of new possibilities in higher education.

Ngibingelela! I am greeting, I request a dialogue which recognises my humanity - this is what essentially lies at the core of the custom of greeting. Dialogical educational models have been discussed in the critical pedagogies tradition in South Africa, through the work of Jansen (2009) and Keet, Zinn and Porteus (2009). A dialogical approach to education underscores the agential capacity of the student, whom through experiential knowledge, inflects the teaching and learning process with new meanings. When declaring oneself, one is seeking an audience with the other, and it is only in contact with the other, that the self becomes awakened to its presence, its complexity and nuances. Through the concept of a pedagogy of mutual vulnerability, Keet, Zinn and Porteus (2009) detail this very notion of self-awareness and the acknowledgement of modes of complicity in structures of domination and oppression. Acknowledging oneself through relationality with the other makes clear the claim that African ontologies are fraught with complexity, which locates these identities at once as the victims of oppression and injustice, yet also as perpetrators of injustice which silenced others, even in precolonial history. 
A decolonial starting position would suggest a concept of delinking, breaking free and away from what has defined as colonial. This entails the rupturing of the space to annihilate existence itself, as a means of creating anew. This thesis is substantiated in the call for the destruction of that which lives presently in order to prepare for the coming of the new people (Mda 2000: 244). Mda's (2000) tale elucidates Nongqawuse's prophecy, which inspired indiscriminate cattle killings ensuing from her foretelling of a new and liberated land, through the proposition of total annihilation. It is in annihilation that the system can be created anew. The annihilation comes with umDlakazi and foreshadows destruction and death; umDlakazi speaks to this very act of cruelty which can otherwise be seen as a form of mercy which creates the system anew. However, there is another alternative, which proposes radical rethinking of the paradigms which constitute our being. A paradigm shift which locates the victor and the victim in a dialogical relation, rather than oppositional binaries is most apt in post-conflictual pedagogies that facilitate the creation of new possibilities.

Barnett (2007) suggests that the development of knowledge and skill can only take place after the Black scholar realises their positionality. I propose that this conundrum, which at once calls for the erasure of history and/or a dialogical approach to the traumas of history, be understood through the lens of the recognition of Blackness. This recognition, at once locates Blackness as victor over those who are subjugated specifically in the context of $u M z i l i k a z i$, while also locating it as the victim of centuries of oppression and subjugation. Mda (2000) explicates this very well in Camagu's appreciation of Qukezwa's ability to play uMrhubhe - an ancient instrument, whose sound carries with it centuries of memory. The dialectics of re-membering and reconstituting Blackness, while aiming to understand how it relates contemporarily to whiteness within the academy, reveals and underscores the role of a dialogical approach in pedagogy, otherwise conceptualised as a pedagogy of obligation. A dialogical approach embraces and recognises these histories, with the aim of teaching to humanise ${ }^{18}$, while holding in consort, what might seem to be

18 The concept of teaching to humanise comes from the stark reality which
characterises South African society as post-conflictual. Humanising here
denotes, facilitating - through the pedagogical journey - a process of learning
which allows the self to identify its own humanity and that of those who would
otherwise be classified as Other. 
opposing identities. Ngibingelela! I am greeting, and declare myself. Ngibingelela, Ngithokozisa! Ngibongela iDlozi, in your personhood, I see the t/old stories of the ancestors. Ngibingelela, through greeting, I acknowledge these variant positionalities of knowing. Ngibingelela, telling history through memories.

Mda (2000) excavates this beautifully in the use of uMrhubhe, in its capacity to represent many worlds simultaneously. Narratives which unfold from positions of exclusion, erasure, and being conceptualised as expendable, become the narratives which define how we think through pedagogical relationality which allows us to fashion new possibilities through complex and entangled histories. The Native of Nowhere thus conceptualised begins to shift our paradigms, through redefining understandings of power, identity and citizenship from an African position in the academy. These positions are neither void of tension, violence nor destruction, what Ramose (2016) calls democratic violence; however, they possess the capacity of liberation through confronting the traumas of the past collectively. It is in the hopes of new possibilities that conflicts arise owing to the failsafe responses which begin, ironically, with the actions of institutional gatekeeping. When uNdlandla is declaring himself, when uJiyane kaNkomose is announcing his arrival, there is either diplomacy or war. UZulu kaSenzangakhona kaJama - isilo - militarises this concept of greeting and declaring oneself at the gates, therefore creating the names and houses which would tell history.

Ngibingelela, I am declaring myself. The imposition of one's positionality upon another seen as uZulu's militarisation of the act of ukubingelela demands recognition and adequate responses; responses which will take seriously the role of trauma in telling and retelling history. Sikhulekile requests that the gates be open. Sikhulekile! read through the lens of a denied request for acknowledgement and recognition suggests the militarisation of language. The move from Ngibingelela, to Sikhulekile, begins a redefinition of positionality, sekuza ngezikhali zaMantungwa - the act of declaration no longer signals a declaration of the self, but rather a declaration of war.

Sikhulekile, after silences and violences, now comes from a positionality of destruction, domination and subjugation as a mode of asserting ones' identity, which further brings with it the act of annihilating those who question the legitimacy of the speaker: these are the implications with which we can understand the concept of Sikhulekile as militarised by uZulu when using an African Vocabulary. Implicit in Ngibingelela, lies the plea to be 


\section{Siseko H. Kumalo}

recognised, to be seen as a human being. Implicit in my reading of Sikhulekile lies the warring narrative of - Baba kashongo, kumnyama lapho sophelela khona. Maye ngacishe ngafa, ngafel'embangweni! Bay'nqumela indaba zesizwe (Buselaphi 2013).

Indigenous narratives, representative of experiential knowledge, do not feature in the structure of knowledge in westernised universities (Grosfoguel 2013), even as they continue to inflect our lived realities. Without the tools to read Indigenous epistemes and the histories which constitute these epistemic positions, the academy continues to deny the humanity of Indigeneity and its existence. Locating our humanity through dialogical relations with fellow Africans only becomes immutable owing to a deficiency in the capacity to see their humanity, a deficiency expressed through xenophobic attacks in the South Africa context for example. These attacks are inherently tied to conceptions of citizenship, identity and the politics of recognition. This complexity foregrounds the decolonial project, which may glean considerable lessons using an African Vocabulary.

Tales of warriors and kings, of civilizations created and annihilated, these tales constitute the Indigenous scholar. In the failure to recognise these epistemic positions, inherently lies the denial of African ontology. Through an inability to narrate these historical narratives in Indigenous languages, I suggest that the academy facilitates and 'sustains hermeneutical injustices' as argued by Maitra (2010: 196). An example of the usefulness of an African Vocabulary is witnessed in how Mqhayi's (1914), Ityala Lamwele reveals numerous considerations for political theory, and social organisation. It is in the quarrel between Babini and Wele (Mqhayi 1914) that we begin to understand the historical approach to matters of power and dispute resolution within Xhosa society as an example. It is through engaging with African writers and scholars that new perspectives can begin to emerge, allowing the academy to teach through an African Vocabulary. Nkosi seeks to define an 'African Vocabulary' (1989: 159) but does not suggest its complexity and abundance $^{19}$. Again, I am not proposing that contemporary African/Black

${ }^{19}$ In White Writing, he suggests that 'if the real Africa will always slip through the net woven by European categories, the question arises whether native African languages may not be in harmony with the landscape as European languages are not' (Nkosi, 1989: 159). The creation of an African Vocabulary suggests whiteness i.e. white settler colonial descendants becoming natives of 
ontology be defined from this perspective, however, I am drawing my readers attention to these complexities which through the philosophical questions they present, give us a wealth of analysis in terms of imagining social organisation, ethics and issues around power and identity in an African context understood through an African experiential framework that does not impose identities from Hull, Manchester, London and Paris. It has been my aim thus, to continue the discussion initiated by Nkosi, while attempting to suggest where we may start to locate an African Vocabulary.

\section{Conclusion}

My primary aim has been to attempt a suggestive definition of an African Vocabulary, while showcasing the complexity inherent in undertaking such a project. It has not been the aim of this work to define a prescriptive conception of Indigeneity, but rather to suggest modes of entry into an African centred analysis of power, ethics and identity. Using an African Vocabulary, I suggest that we are presented with a lexicon which contends with coeval relationships of identities that may seem at first glance - at odds with each other - but in fact can and do co-exist. It is in the exchange which takes place through greeting, wherein we are enlightened about the questions of power and identity as understood in Zulu epistemology, therefore facilitating a paradigmatic shift in the teaching and learning processes of the university, and subsequently creating a pluriversity. It is in recognising the humanity of those who are relegated to the periphery, and giving voice to the voiceless, that we begin to piece together histories, power relations and domination, which informed ways of governance in our African lineages and societies. Taking seriously Grosfoguel's (2012) argument, which challenges the hegemony of French, German, Anglo-America and British power in the knowledge production processes, we are pressed to piece together our histories and create new possibilities from our own locales.

the land, which as Nkosi suggests '[they] would have to know the language like a native, sharing the modes of consciousness of the people born to it, and to that extent giving up [their] European identity' (1989: 159). An African Vocabulary as such denotes the creation of settler colonial identities anew; a re-creation which locates them in relation to native subjectivities and identities. 
However, what are the philosophical questions which arise from this systematic analysis? I would suggest that the concept of umDlakazi as an option to higher education transformation signals the entry point into these questions. UmDlakazi here reveals the interplay between ethics and power. The interplay between ethics and power gives rise to the consideration of whether the concept of umDlakazi undermines dialogical pedagogical strategies which further invites the question of whether the concept of umDlakazi centres anyone within the pedagogical journey? Owing to how we understand umDlakazi, one ought to further ask, how then is the post-colonial condition defined. This, specific, question is inspired by Prah (2017). Further we ought to carefully think through the question of who is a legitimate subject/ citizen in the post-colonial pedagogical space? What are the implications of being an illegitimate subject and can education play a role in ameliorating the postcolonial dilemma? Resultantly, what is the role of the African Vocabulary in answering these questions? I would suggest that further research be undertaken with the aim of answering these questions, as such giving rise to the continued debate and development of an African Vocabulary in our context.

Reconceptualising the project of knowledge production from a perspective which is informed by indigenous subjectivity plays a critical role in centring African epistemic positions in the university. With the aim of articulating an African Vocabulary, this analysis has centred the role of oral history through the use of the clan names of uMagubane noKumalo. An African Vocabulary, has revealed how competing identities can co-exist, therefore, showcasing the need to include these histories in contemporary pedagogical praxes. The inclusion of these epistemic positions allows the university to navigate contemporarily envisaged challenges, which manifest as the 'contestation of visibilities' (Kumalo 2018: 3). Through a detailed semantic analysis, I have argued for epistemic justice as the recognition of Indigeneity (Praeg 2014). Resisting impositions on Black epistemology - maintained through modes of teaching and learning employed by the westernised university which finds itself in South Africa - begins by using an African Vocabulary. My aim, through proffering a suggestion of an African Vocabulary, has been to challenge hegemonic ways of thinking in the academy. 


\section{References}

Abrahams, Y. 2003. Colonialism, Dysfunction and Disjuncture: Sarah Bartman's Resistance (Remix). Agenda: Empowering Women for Gender Equity 17,58: 12-26. Available at:

https://www.tandfonline.com/doi/pdf/10.1080/10130950.2003.9674488 (Accessed on 01 March 2016.)

Almeida, S. 2015. Four: Race-Based Epistemologies: The Role of Race and

Dominance in Knowledge Production. Wagadu: A Journal of Transnational Women's and Gender Studies 13,1: 79-105. Available at: https://search.proquest.com/openview/7d27d2c12d80e65f23e5744ffbcdc 04bb/1?pq-origsite $=$ gscholar\&cbl $=40412$

(Accessed on 24 February 2016.)

Barnett, R. 2007. Assessment in Higher Education: An Impossible Mission? In Boud, D. \& N. Falchikov (eds): Rethinking Assessment in Higher Education: Learning for the Long Term. London \& New York: Routledge. Bhabha, H.K. 1983. The Other Question: Stereotype, Discrimination and the Discourse of Colonialism. In Barker, H.A., M. Diawara, R.H. Linderborg \& S. Best (eds.): Black British Cultural Studies: A Reader. Chicago \& Illinois: University of Chicago Press.

Boud, D. \& N. Falchikov 2007. Introduction: Assessment for the Long Term. In Boud, D. \& N. Falchikov (eds.): Rethinking Assessment in Higher Education: Learning for the Long Term. London \& New York: Routledge. https://doi.org/10.4324/9780203964309

Buselaphi 2012. Umendo. [CD-ROM]. Johannesburg, South Africa: Gallo Record Company.

Buselaphi 2015. Inkunzi Emalunde. [CD-ROM]. Johannesburg, South Africa: Tox Music.

Coetzee, J.M. 1988. White Writing: On the Culture of Letters in South Africa. Johannesburg: Radix Publishers.

Das, V. 2007. Language and Body: Transactions in the Construction of Pain. In Das, V. Life and Words: Violence and the Descent into the Ordinary. Berkley: University of California Press.

DiAngelo, R. 2011. White Fragility. International Journal of Critical Pedagogy 3,3: 54 - 70. Available at:

http://libjournal.uncg.edu/ijcp/article/view/249/116

(Accessed on 28 November 2015.) 
Falola, T. \& M.M. Heaton 2008. Transition to British Colonial Rule, 18501903. In Falola, T. \& M.M. Heaton (eds.): A History of Nigeria.

Cambridge, New York, Melbourne, Madrid, Cape Town, Singapore, Sao Paulo \& Delhi: Cambridge University Press.

Fricker, M. 2007. Epistemic Injustice: Power and the Ethics of Knowing, Oxford \& New York: Oxford University Press.

https://doi.org/10.1093/acprof:oso/9780198237907.001.0001

Gordimer, N. 1988. The Essential Gesture: Writing, Politics and Places. Johannesburg: Taurus Publishers.

Gordin, L.R. 2014. Justice Otherwise: Thoughts on Ubuntu. In Praeg, L. \& S. Magadla (eds.): Curating the Archive. Pietermaritzburg: University of KwaZulu-Natal Press.

Grosfoguel, R. 2007. The Epistemic Decolonial Turn: Beyond PoliticalEconomy Paradigms. Cultural Studies 22,2: 211 - 223. Available at: https://www.tandfonline.com/doi/pdf/10.1080/09502380601162514?nee $\underline{\text { dAccess }=\text { true }}$

(Accessed on 12 November 2015.)

https://doi.org/10.1080/09502380601162514

Grosfoguel, R. 2009. Human Rights and Anti-Semitism after GAZA. Human Architecture: Journal of the Sociology of Self-Knowledge 7,2: 89 - 102. Available at:

http://www.scielo.org.co/scielo.php?pid=S0120-

$\underline{48072009000200010 \& \text { script }=\text { sci_arttext\&tlng=en }}$

(Accessed on 15 January 2016.)

Grosfoguel, R. 2012. Decolonizing Western Uni-versalisms: Decolonial Pluriversalim from Aimé Césaire to the Zapatistas. Transmodernity: Journal of Peripheral Cultural Production of the Luso-Hispanic World 1,3: 88 104.

Grosfoguel, R. 2013. The Structure of Knowledge in Westernized Universities: Epistemic Racism/ Sexism and the Four Genocides/ Epistemicides of the Long $16^{\text {th }}$ Century. Human Architecture: Journal of the Sociology of SelfKnowing 11,1: 73 - 90.

Gqola, P.D. 2001. Defining People: Analysing Power, Language and Representation in Metaphors of the New South Africa. Transformation 47: 94 - 106. Available at:

https://pdfs.semanticscholar.org/7536/5d5ebdea121241ff56ca6cb59179d 42a158a.pdf 
(Accessed on 01 March 2016.)

Gqola, P.D. 2012. Ufanele Uqavile: Blackwomen, Feminisms and Postcoloniality in Africa. Agenda: Empowering Women for Gender Equity 16,50: 11 - 22. Available at:

https://www.tandfonline.com/doi/pdf/10.1080/10130950.2001.9675990? needAccess =true (Accessed on 01 March 2016.)

Gyekye, K. 1998. Person and Community in African Thought. In Coetzee, P.H. \& A.P.J. Roux (eds.): The African Philosophy Reader. New York: Routledge Publishers.

hooks, b. 1992. Black Loos: Race and Representation. Boston: South End Press.

Jansen, J.D. 2009. Knowledge in the Blood: Confronting Race and the Apartheid Past. Stanford: Stanford University Press.

Keet, A., D. Zinn \& K. Porteus 2009. Mutual Vulnerability: A Key Principle in a Humanising Pedagogy in Post-conflictual Societies. Perspectives in Education 27, 2: 109 - 119. Available at:

https://s3.amazonaws.com/academia.edu.documents/3439771/Keet_Mut ual 2009 .pdf?AWSAccessKeyId=AKIAIWOWYYGZ2Y53UL3A\&Ex pires $=1539558871 \&$ Signature $=\operatorname{dekDj0dlZu4KqL\% 2Fx~YLjeU7k21rk\% 3}$ D\&response-content-

disposition=inline\%3B\%20filename\%3DMutual_Vulnerability_a_Key_ Principle In.pdf (Accessed on 10 March 2014.)

Kumalo, S.H. 2018. Explicating Abjection - Historically White Universities Creating Natives of Nowhere? Critical Studies in Teaching and Learning (CriSTaL) 6,1:1-17. Available at:

https://journals.co.za/docserver/fulltext/cristal_v6_n1_a2.pdf?expires=1 $\underline{539555354 \& \mathrm{id}=\mathrm{id} \& \text { accname }=\text { guest } \& \text { checksum }=\mathrm{F} 45 \mathrm{D} 48635 \mathrm{~F} 74 \mathrm{C} 8000}$ B686BF188DB9068 (Accessed on 07 July 2018.)

Lebakeng, J.T., M.M. Phalane \& N. Dalindjebo 2006. Epistemicide, Institutional Cultures and the Imperative for the Africanisation of Universities in South Africa. Alternation 13,1: 70 - 87.

Available at:

http://journals.co.za/docserver/fulltext/alt/13/1/548.pdf?expires=152311 7500\&id=id\&accname $=$ guest $\&$ checksum $=6$ BDFA8A538AB0B7E92CC 164113AA1253 (Accessed on 23 November 2015.)

Maitra, I. 2010. The Nature of Epistemic Injustice. Philosophical Books 51,4: 195 - 211. Available at: 
https://onlinelibrary.wiley.com/doi/epdf/10.1111/j.1468-

0149.2010.00511.x (Accessed on 16 December 2016.)

https://doi.org/10.1111/j.1468-0149.2010.00511.x

Mamdani, M. 2005. Political Identity, Citizen and Ethnicity in Post-Colonial Africa. Arusha Conference. New Frontiers of Social Policy 12/15/2005, presented at the World Bank conference.

Mamdani, M. 2013. Define and Rule: Native as Political Identity. Johannesburg: Wits University Press.

Mda, Z. 2000. The Heart of Redness. Cape Town: Oxford University Press.

Menkiti, I.A. 1984. Person and Community in African Traditional Thought. In:

Wright, R.A. (ed.): African Philosophy: An Introduction. Lanham:

University Press of America.

Minh-ha, T. 1989. Woman, Native, Other. Bloomington and Indianapolis: Indiana University Press.

Mohanty, S.P. 1993. The Epistemic Status of Cultural Identity: On 'Beloved' and the Postcolonial Condition. Cultural Critique 24: 41 - 80.

Available at:

http://www.jstor.org/stable/pdf/1354129.pdf?refreqid=excelsior\%3Acad d1b8d943a72e555a14cd2aa5f6cb5

(Accessed on 12 June 2016.)

https://doi.org/10.2307/1354129

Mqhayi, S.E.K. 1970/1981. Ityala Lamawele. Lovedale: Lovedale Press.

Nkosi, L. 1989. Review: White Writing. Third World Quarterly 11,1: 157 -

161. Available at: https://doi.org/10.1080/01436598908420145

(Accessed on 23 December 2015.)

Patel, E. 1975. The World of Nat Nakasa: Selected Writings of the Late Nat Nakasa. Johannesburg: Ravan Press.

Praeg, L. 2014. A Report on Ubuntu. Scottsville: University of KwaZulu-Natal Press.

Prah, K.K. 2017. The Intellectualisation of African Languages for Higher Education. Alternation 24, 2: 215 - 225. Available at:

http://alternation.ukzn.ac.za/Files/articles/volume-24/issue-2/11-Prah-

$\underline{\text { F.pdf }}$

(Accessed on 13 September 2018.)

https://doi.org/10.29086/2519-5476/2017/v24n2a11

Ramose, M.B. 2016. Modu Wa Taba. Unpublished paper. First Draft Intended for The Leadership of Transformation and the Transformation of Lead- 
ership in Higher Education - 2016, Rhodes University.

Rutherford, J. (ed.) 1990. The Third Space: Interview with Homi, K. Bhabha. In Identity: Community, Culture, Difference. London:Lawrence \& Wishart. Tuck, E. \& K.W. Yang 2012. Decolonization is not a Metaphor. Decolonization: Indigeneity, Education and Society 1,1: 1 - 40.

Available at:

http://bussigel.com/communityart/wp-content/uploads/2017/08/1863043263-1-PB.pdf

(Accessed on 23 June 2016.)

Siseko. H. Kumalo Philosophy Department University of Pretoria South Africa jdd@up.ac.za 